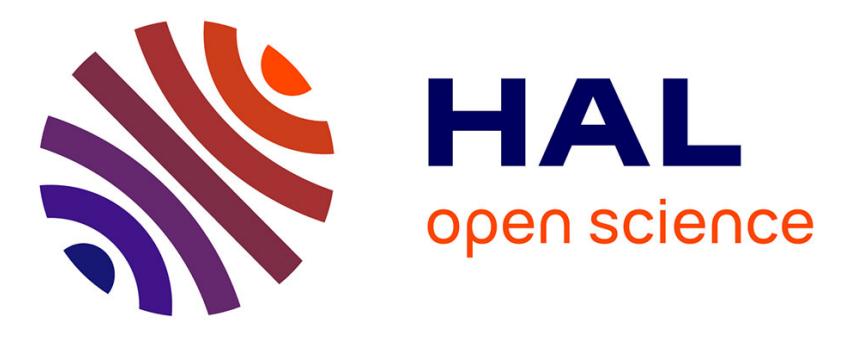

\title{
Advanced departure dates in long-distance migratory raptors
}

Ondine Filippi-Codaccioni, Jean-Pierre Moussus, Jean-Paul Urcun, Frédéric Jiguet

\section{- To cite this version:}

Ondine Filippi-Codaccioni, Jean-Pierre Moussus, Jean-Paul Urcun, Frédéric Jiguet. Advanced departure dates in long-distance migratory raptors. Journal für Ornithologie $=$ Journal of Ornithology, 2010, 151 (3), pp.687-694. 10.1007/s10336-010-0500-5 . hal-00575246

\section{HAL Id: hal-00575246 https://hal.science/hal-00575246}

Submitted on 10 Mar 2011

HAL is a multi-disciplinary open access archive for the deposit and dissemination of scientific research documents, whether they are published or not. The documents may come from teaching and research institutions in France or abroad, or from public or private research centers.
L'archive ouverte pluridisciplinaire HAL, est destinée au dépôt et à la diffusion de documents scientifiques de niveau recherche, publiés ou non, émanant des établissements d'enseignement et de recherche français ou étrangers, des laboratoires publics ou privés. 


\title{
Advanced departure dates in long-distance migratory raptors
}

\author{
Ondine Filippi-Codaccioni · Jean-Pierre Moussus • \\ Jean-Paul Urcun · Frédéric Jiguet
}

Received: 12 October 2009/Revised: 12 January 2010/Accepted: 1 February 2010/Published online: 10 March 2010

(C) Dt. Ornithologen-Gesellschaft e.V. 2010

\begin{abstract}
Evidences for phenological changes in response to climate change are now numerous. One of the most documented changes has been the advance of spring arrival dates in migratory birds. However, the effects of climate change on subsequent events of the annual cycle remain poorly studied and understood. Moreover, the rare studies on autumn migration have mainly concerned passerines. Here, we investigated whether raptor species have changed their autumn migratory phenology during the past 30 years at one of the most important convergent points of western European migration routes in France, the Organbidexka pass, in the Western Pyrenees. Eight out of the 14 studied raptor species showed significant phenological shifts during 1981-2008. Long-distance migrants displayed stronger phenological responses than short-distance migrants, and advanced their mean passage dates significantly. As only some short-distance migrants were found to delay their autumn migration and as their trends in breeding and migrating numbers were not significantly negative, we were not able to show any possible settling process of raptor populations. Negative trends in numbers of migrating raptors were found to be related to weaker
\end{abstract}

Communicated by F. Bairlein.

O. Filippi-Codaccioni $(\varangle) \cdot$ J.-P. Moussus $\cdot$ F. Jiguet

Muséum National d'Histoire Naturelle,

UMR 7204 MNHN-CNRS-UPMC «Conservation des Espèces,

Restauration et Suivi des Populations»,

CP51, 55 rue Buffon, 75005 Paris, France

e-mail: ofc@mnhn.fr

O. Filippi-Codaccioni · J.-P. Urcun

Ligue pour la Protection des Oiseaux,

LPO Aquitaine, 109 quai Wilson,

33130 Bordeaux, France phenological responses. Further studies using data from other migration sites are necessary to investigate eventual changes in migration routes and possible settling process.

Keywords Climate change - Migrating birds . Trans-Saharan $\cdot$ Mean passage dates $\cdot$ Phenology

\section{Introduction}

Living organisms displayed various responses to 30 years of climate warming at the end of the twentieth century (Walther et al. 2002). Among the most documented responses are temporal shifts in species phenology, witnessed thanks to long-term monitoring datasets. Many studies reported advances in the seasonal start of breeding or growth in numerous animal and plant species. Among them, the ones on migratory birds' spring arrival dates in Europe have been particularly noteworthy (Sokolov et al. 1998; Lehikoinen et al. 2004; Sparks et al. 2005; Jonzén et al. 2006; Zalakevicius et al. 2006). However, the effects of climate change on subsequent events of the annual cycle, like autumn migration, remain poorly studied and understood (but see Jenni and Kéry 2003; Tøttrup et al. 2006; Thorup et al. 2007). Evidence for a delayed or advanced autumn migration was equivocal in numerous studies with some species departing earlier and others later (Gatter 1992; Bairlein and Winkel 2001; Gilyazov and Sparks 2002; Lehikoinen et al. 2004). In fact, the phenological response often depends on specific life history traits (Lehikoinen et al. 2004). Indeed, Jenni and Kéry (2003) showed for 65 passerine species that the temporal trend in peak passage date depended on several specific life history traits like the migration strategy, the number of broods or the main food type. 
As most studies have been undertaken on passerines, taking advantage of the numerous migration observatories, raptor migration phenology - as well as its phenological changes according to specific life-history traits-remains poorly investigated.

Here, we chose to study these possible phenological shifts using migration counts of visually-detected migrants at one of the most important convergent points of major western European migration routes in France, the Organbidexka pass, Western Pyrenees. To achieve this, we computed mean passage dates weighted by species abundance for 14 raptor species over a 28-year period (19812008), and looked for long-term trends in these mean dates. We further tested whether among-species variations in these long-term trends depended on several traits. Firstly, migration strategy: we predicted long-distance migrants to advance their migration dates in autumn. Indeed, there are several advantages to departing earlier. Their survival could increase if they are able to track ecological changes due to climate change en route as well as on the wintering grounds (i.e. the onset of the dry season in the Sahel from September onwards) (Jenni and Kéry 2003). They could also find better winter territories if arriving earlier than other non-nomadic wintering species thus resulting in better body condition in preparation for spring migration (Alerstam 1990; Newton 2008). Some evidence also shows that raptors are able to advance their breeding phenology due to increased spring temperature which enables them to depart earlier (Lehikoinen 2009; Lehikoinen et al. 2009). In contrast, we predicted short-distance migrants to delay their departure dates. Indeed, as they winter in areas offering better conditions resulting from global warming, they may delay autumn migration or even winter in the breeding grounds (Berthold 1990). They could thus achieve higher survival rates and/or obtain higher quality breeding territories by arriving earlier in spring (Berthold 1990; Jenni and Kéry 2003; Newton 2008). Secondly, moult strategy: arrival and departure dates could be linked to moult timing. Moulting some flight feathers is necessary each year in raptors but cannot occur simultaneously with migration because it reduces their gliding ability. Species replacing large flight feathers (wings and tail) before migration could be more constrained and depart later than the others. And thirdly, generation time: if selection for a changing phenology in response to a changing climate is occurring, it could occur more rapidly in species with a shorter generation time.

Next, we looked at the relationship between population trends (as available for European breeding populations) and our estimated temporal trends in species phenology of migration in the 14 raptor species considered. In European birds (Møller et al. 2008), most declining species could be those displaying the least phenological responses to climate change. We made this prediction with trends related to breeding populations. As trends of migrating species could both signify a settling process (reduction of the migratory behaviour within a constant population size) or a decline in population size, we also found it of interest to test this relationship with trends of migrating raptors at Organbidexka.

\section{Methods}

Study site

The Western Pyrenees and their passes constitute one of a few convergent points along the most important western European migration flyways. The main pass there for raptor migration is the Organbidexka pass $\left(43^{\circ} 02^{\prime} 19.06^{\prime \prime} \mathrm{N}\right.$, $\left.1^{\circ} 00^{\prime} 21.68^{\prime \prime} \mathrm{W}\right)$. It is located in the Basque Country, in the department of Pyrénées-Atlantiques (south-west France), lying $1,283 \mathrm{~m}$ above sea level. It is one of the most important migration sites in Western Europe together with Falsterbo (Sweden) and the Strait of Gibraltar (Spain), particularly for the observation of raptors, storks, cranes and pigeons.

\section{Data on bird migration}

At the pass, annual autumn surveys are conducted from 15 July to 15 November from dawn to dusk by varying numbers of observers among which permanent skilled ones are present throughout the period. Annual counts of raptors average $\sim 40,000$. We used a dataset comprising 28 years of migration counts, from 1981 to 2008 , with the same data recording methodology used during the whole period (Devisse and Urcun 1994). Daily numbers of birds flying south were used for analyses.

Tested traits were taken from different sources: generation time and migration strategy from (Birdlife International 2004), moult strategies from Cramp et al. (1977-1984). Trends for European breeding populations were taken from Birdlife International (2004) and transformed using a 6-level scale (as in Møller et al. 2008), ranging from large decline to moderate increase (mentioned as "TrendEU" hereafter), while local trends in numbers migrating at Organbidexka were calculated as slopes of total annual counts by species as a function of years (hereafter "TrendOrg") (Table 1). Two categories designed migration strategy: short-distance migrants which winter in Europe and North Africa, and long-distance migrants which winter south of the Sahara. The Marsh Harrier (Circus aeruginosus) was classified as a long-distance migrant because birds passing the Pyrénées originate from northern European breeding populations, which winter mainly in sub-Saharan Africa (Strandberg et al. 2008). 


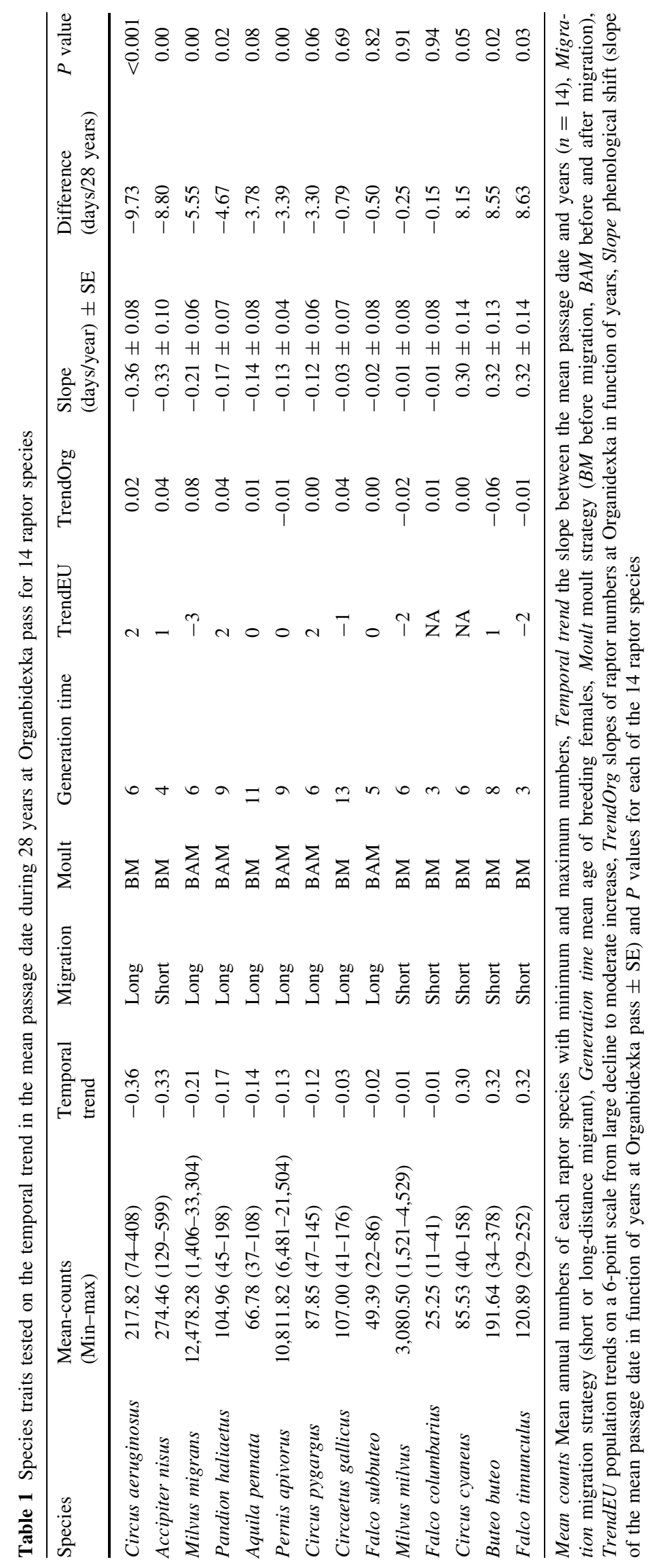


Statistical analyses

Various phenological modelling methods designed to compute phenological shifts exist in the literature. These include first appearance dates (Sparks et al. 2005; reviewed in Lehikoinen et al. 2004), mean or median dates (Sokolov et al. 1998; Vähätalo et al. 2004; Sparks et al. 2005), different percentiles (Jonzén et al. 2006) or smoothing techniques (Knudsen et al. 2007). Although the accuracies of these methods have still not been extensively compared, first appearance dates and other methods relying on a small portion of the total phenological distribution have aroused major criticism (Tryjanowski and Sparks 2001; MillerRushing et al. 2008). The issue is even more crucial with raptor migration phenology as some species display a bimodal phenological distribution due to different passage dates between males and females or between adults and juveniles. Moreover, there was an important variation in sample size between years in our data, with up to $50 \%$ variations between the annual counts. To deal with these issues, the two most robust methods are the mean passage dates and the smoothing techniques which both take the entire phenological distribution into account and compute sensible estimates for bimodal phenological distributions (Moussus et al., unpublished results). The results which are presented here relate to the estimates computed using the mean passage dates, while the results we obtained with phenological shift estimates from the smoothing method are very similar. Indeed, there is a strong correlation between estimations of the phenological shifts between the two methods which range between $r=0.55, n=28$, $P=0.002$ for the Merlin (Falco columbarius), and $r=0$ $0.98, n=28, P<0.001$ for the European Sparrowhawk (Accipiter nisus) with a mean Pearson's coefficient $r=0.90 \pm 0.11$ for the 14 species. Methodological details of the smoothing method are available in Moussus et al. (2009).

The temporal trend of mean passage dates was modelled using linear models and tested using analyses of variance (ANOVAs). Adjusted effects of moult date, migration strategy and generation time on the temporal trend in mean passage dates were tested using linear models and ANOVAs. Relationships between the temporal trend of mean passage dates and species population trends were modelled using linear models and statistical significance of trends tested with ANOVAs. Population trends effect was first adjusted to migration and moult strategies as well as to generation time. We computed the contribution of each explanatory term to the variation in the responses after fitting all other terms in the models.

To avoid considering too imprecise data, Vähätalo et al. (2004) omitted from their analysis the species data for years when less than 20 individuals were counted. In our case, this restriction would apply only for the Merlin. If we restrict the species-specific dataset to years with at least 20 individuals detected, 8 years have to be deleted. Considering only the remaining years with more than 20 birds changed the temporal trend of mean migration dates from $-0.01 \pm 0.08$ to $-0.09 \pm 0.09$, but did not affect the outputs of the other analyses.

All analyses were conducted using the $\mathrm{R}$ statistical software (R Development Core Team 2006).

\section{Results}

Phenological shifts during the last 28 years were significant for 8 out of the 14 species. They ranged from an advance of 10 days for the Marsh Harrier to a delay of 9 days for the Common Kestrel (Falco tinnunculus) (Table 1). In addition, two species, Booted Eagle (Aquila pennata) and Montagu's Harrier (Circus pygargus), had $P$ values lower than 0.10 (Table 1).

\section{Relationship to life history traits}

Migration strategy was found to explain significantly the changes in phenology $\left(F_{1,10}=5.83, P=0.03\right)$ when adjusted for moult strategy $\left(F_{1,10}=0.84, P=0.37\right)$ and generation time $\left(F_{1,10}=1.72, P=0.21\right)$. The model with migration strategy as a single predictor explained $33 \%$ of the total variance $\left(F_{1,12}=5.92, P=0.03\right)$. Other traits did not relate to the temporal trend in mean passage dates when tested separately. Long-distance migrants showed a significant negative slope in their temporal trend in mean passage dates (mean $\pm \mathrm{SE}$ : $-0.14 \pm 0.06, \quad P=0.04) \quad$ whereas short-distance migrants showed a non-significant positive slope (mean \pm SE: $0.09 \pm 0.07, P=0.23$; Fig. 1 ).

None of the studied long-distance migrants ( 8 species) delayed its autumn migration during the last 30 years, while 3 out of the 6 short-distance migrants delayed their passage dates significantly (e.g. Fig. 2; Table 1).

Within the same genus, comparisons between species are noted. For example, Montagu's and Hen Harriers (Circus cyaneus) display very different responses to climate change. The first is a long-distance migrant and has advanced its migration date, while the second winters in Europe and North Africa and has delayed its migration. Among the genus Falco, responses are also contrasted. Only the Common Kestrel which can be classified as a short-distance migrant, displayed a strong response (as a delay) in mean passage dates temporal trends whereas the Merlin did not respond at all. As a long-distance migrant, the Eurasian Hobby (Falco subbuteo) did not show significant earlier migration dates. 


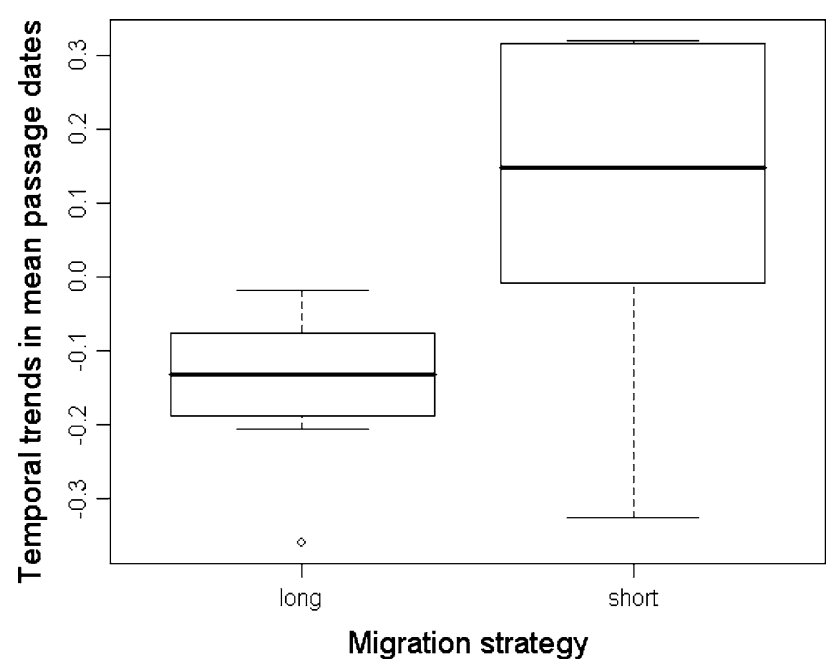

Fig. 1 The temporal trends in mean passage dates as a function of the migration strategy (short- or long-distance) for 14 raptor species migrating at the Organbidexka pass, Western Pyrenees in southern France

Relationship to population trends

We failed to find a significant negative relationship between the trends in European breeding populations (TrendEU) and the temporal trends in mean passage dates $\left(F_{1,10}=1.17\right.$, $\left.R^{2}=10.5 \%, P=0.30\right)$, whereas the trends in migrant numbers at Organbidexka (TrendOrg) and the temporal trends of mean passage dates were found to be negatively and significantly correlated $\left(F_{1,12}=8.73, R^{2}=42 \%, P=\right.$ 0.01 ) (Fig. 3). When adjusted for the effect of migration and moult strategies and of generation time, the relationship between breeding populations trends and trends in phenology remained non-significant, while the one between migrating numbers trends and temporal trends in mean passage dates become non-significant (TrendEU: $F_{1,7}=0.48, P=0.50$; TrendOrg: $F_{1,9}=2.98, P=0.11$ ).

We found a significant difference in trends of migrating raptor numbers according to the migration strategy $\left(F_{1,376}=41.15, P<0.001\right)$.

Migrating and breeding trends were not correlated when considering all species $\left(F_{1,10}=0.32, \quad R^{2}=0.03\right.$, $P=0.57)$. There was no difference in this relationship between migration strategies (TrendEU $\times$ migration strategy: $\left.F_{1,8}=0.58, P=0.46\right)$

\section{Discussion}

\section{Phenological trends}

The main result is that long-distance migrants advanced their autumn migration during this 28-year period, while some, though not all, short-distance migrants delayed their
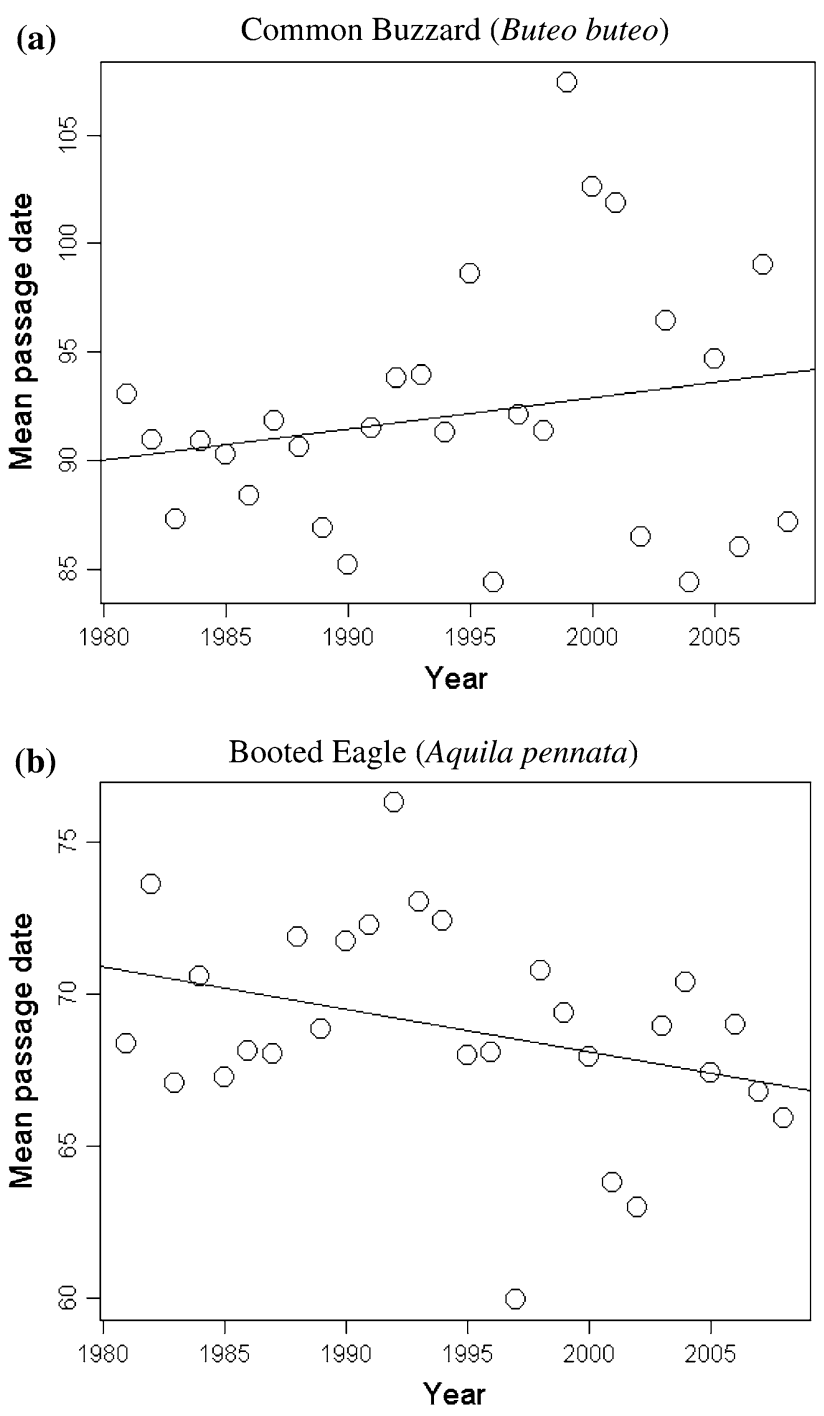

Fig. 2 Examples of changes in the migratory phenology during 28 years by a a short-distance migrant, the Common Buzzard (Buteo buteo) and $\mathbf{b}$ a long-distance migrant, the Booted Eagle (Aquila pennata). Mean dates are given in number of days, day 1 being 12 July

passage. Apparently, raptors display the same dichotomic response as passerines according to their migration strategy (Jenni and Kéry 2003) which is in favour of a common pattern of the response among birds to global climate change, the same constraints driving the same adaptations even for bird species with very different demographic traits.

However, some exceptions remain within short-distance migrants suggesting that other traits could be responsible for the change in migratory phenology. For example, the Eurasian Sparrowhawk showed a great advance in its mean passage dates whereas it is classified as short-distance migrant. It could be possible that an important part of individuals passing at Organbidexka are long-distance 

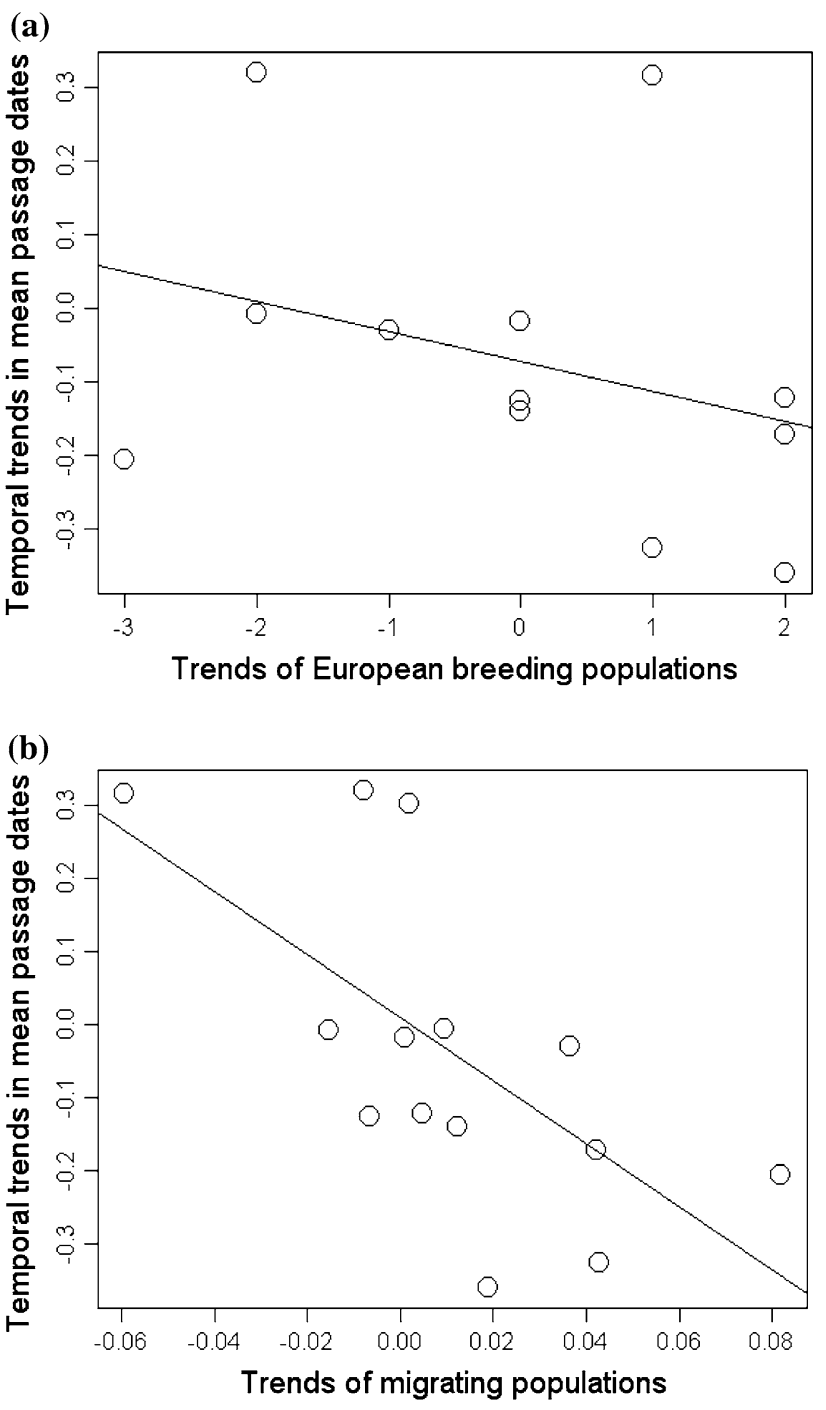

Fig. 3 Relationship between the temporal trends in mean passage dates and $\mathbf{a}$ trends of European breeding populations and $\mathbf{b}$ trends of migrants counted at Organbidexka

migrants. Another explanation could be that the Sparrowhawk is a predator specialized on passerines, in contrast to the other short-distance delaying species (Hen Harrier, Common Kestrel and Common Buzzard) which feed on small mammals. Small mammals do not migrate but occur all over the Europe year round while passerines are mainly migratory. Sparrowhawks are possibly trying to migrate with the passerines whereas mammal eaters do not need to do so (Lehikoinen 2009).

Lehikoinen (2009) found the same advance of autumn migration in Sparrowhawks. The advance was in accordance with an earlier breeding schedule. The author found differences between early migrating young that have advanced their autumn migration and late-phase migrants, mainly representing adults, which have not advanced their autumn schedule. As we here referred to mean migration dates, it is possible that our pattern of advanced migration is explained mainly by juvenile Sparrowhawks which would be more numerous than adults (Thorup et al. 2007). Two hypotheses have been proposed regarding the effects of climate change on the autumn phenology of migratory birds. Jenni and Kéry (2003) suggested that single-brooded short-distance migrants, such as Sparrowhawks, should show delayed rather than advanced autumn phenology despite advancing spring arrival (Lehikoinen 2009). Because of the warming climate, it would be beneficial for those species to winter as close to breeding areas as possible with respect to earlier arrival and territory establishment (Jenni and Kéry 2003; Newton 2008). On the other hand, Tøttrup et al. (2006) have documented advancing autumn migration times in many northern European shortand long-distance migrating passerines. These authors hypothesized that the time spent by the species on their breeding areas is constant, and thus earlier spring arrival and breeding would lead to an earlier autumn migration of both adult and young birds (Thorup et al. 2007). Taken as a whole, our migration data on Sparrowhawks would provide support for the hypotheses of Thorup et al. (2007) as we found an advance of autumn migration for this species despite it being a short-distance migrant (Cramp et al. 1977-1994; Birdlife International 2004). However, a closer look at the differential migration between ages or sexes could highlight that different groups of the same species may respond differently to climate change, making it possible to test both hypotheses (Lehikoinen 2009).

We did not find any significant response in temporal trends of mean passage dates of one short-distance species, the Merlin, and of one long-distance migrant, the Eurasian Hobby which did not show significant earlier migration dates. Organbidexka is possibly not the best migration site to study phenological trends of these two falcons, as these species present the smallest mean annual counts out of our 14 species (Table 1) and therefore significant phenological shifts could be harder to detect. This could prevent us from finding any temporal trend in mean passage dates.

Relationship between phenological shifts and population trends

No relationship was found between breeding population trends and temporal trends in mean passage dates. We could have expected species whose breeding populations are increasing to display the strongest advances in autumn migration, as found by Møller et al. (2008) for 100 European species using breeding population trends and spring arrival timing. As autumn migration timing is often related to the timing of spring events (Sokolov 2006), we suggest that species which advanced their spring migration would have also advanced their autumn migration. Consequently, 
those species which have advanced their autumn migration would be expected to have better population trends.

It is possible either that our sample size is not large enough to give evidence of such effects or that there is no such relationship in raptors.

Conversely, species-specific decreases in migrating numbers tend to be associated with the latest mean passage dates. However, if a decrease in counted numbers on the breeding grounds can be interpreted as a decline of breeding population numbers, this does not apply to migration counts. A decrease in migrating numbers can also ensue from a disappearance of the migratory behaviour even if the global population size is stable, a case of some putative ongoing settling process. We here have no proof of such possible ongoing settling process for "European" migrant raptors as only some short-distance migrants delayed their migration and as this species group did not show significant negative trends in migration counts.

Further investigations on the link between recapture distances taken from ringing database for those species suspected to have begun a settling process (Common Buzzard, Common Kestrel) would be necessary to highlight this possible phenomenon. We can add that evidence of a shortening of the distance between breeding and wintering sites has been recently shown for 24 bird species and that it has been proposed as a possible explanation for the stronger advancement of arrival date found in several short-distance species relative to long-distance migrants (Visser et al. 2009). Among them, Hen Harrier, Common Kestrel and Common Buzzard showed significant decreases in their winter recapture distances-and delayed their mean passage date at Organbidexka - while Sparrowhawk and Marsh Harrier did not show such significant decreases-both migrate earlier at Organbidexka. Comparisons between trends detected at other migration sites like Gibraltar and Falsterbo would also be worthwhile.

\section{Zusammenfassung}

\section{Verfrühte Herbstzugtermine bei langstreckenziehenden} Greifvögeln

Hinweise für phänologische Veränderungen als Antwort auf den Klimawandel sind inzwischen zahlreich. Eine der am häufigsten dokumentierten Veränderungen sind die früheren Ankunftsdaten der Zugvögel im Frühjahr. Jedoch bleibt bis jetzt der Einfluss von Klimaveränderungen auf aufeinanderfolgende Ereignisse des Jahreslaufes schlecht untersucht und verstanden. Darüber hinaus beschäftigten sich die wenigen Studien zum Herbstzug hauptsächlich mit Singvögeln. In dieser Studie untersuchten wir, ob es in den letzten 30 Jahren im Herbstzug von Greifvögeln eine phänologische Veränderung an einem der wichtigsten Durchzugspunkte der westeuropäischen Zugrouten in Frankreich, dem Organbidexka Pass der westlichen Pyrenäen, gab. Acht der vierzehn untersuchten Greifvogelarten zeigten phänologische Verschiebungen während der Jahre 1981-2008. Langstreckenzieher zeigten deutlichere phänologische Reaktionen als Kurzstreckenzieher und verfrühten ihren mittleren Durchzugstermin signifikant. Da nur einige Kurzstreckenzieher ihren Herbstzug verspäteten und da ihr Trend in Brut- und Zugzahlen nicht signifikant negativ war, konnten wir keine möglichen Veränderungen ihrer Zugbereitschaft nachweisen. Rückgänge in den Zahlen durchziehender Greifvögel korrelierten mit schwächeren phänologischen Reaktionen. Weitere Studien mit Daten anderer Durchzugsgebiete sind notwendig, um mögliche Änderungen in Zugrouten und Zugbereitschaft zu untersuchen.

Acknowledgments We would like to thank the many volunteers counting birds at Organbidexka for many years, since the beginning of the migration observatory. We are grateful to Marc Kéry and Aleksi Lehikoinen for their helpful comments. We also thank the Ligue de Protection des Oiseaux and Organbidexka Col Libre, joined into the ORMO Program (Regional Observatory of Bird Migration in Aquitaine), for funding this research and providing the data.

\section{References}

Alerstam T (1990) Bird migration. Cambridge University Press, New York

Bairlein F, Winkel W (2001) Changes and risks. In: Lozan JL, Graûl $\mathrm{H}$, Hupfer P (eds) Climate of the 21 st century. Wissenschaftliche Auswertungen, Hamburg, pp 278-282

Berthold P (1990) Vogelzug. Wissenschaftliche Buchgesellschaft, Darmstadt

Both C, van Asch M, Bijlsma RG, van den Burg AB, Visser ME (2009) Climate change and unequal phenological changes across four trophic levels: constraints or adaptations? J Anim Ecol 78:73-83

Cramp S, Simmons KEL, Perrins CM (eds) (1977-1994) Birds of the western Palearctic, vol. 9. Oxford University Press, Oxford

Devisse J-S, Urcun J-P (1994) Mise en place du suivi de populations européennes d'oiseaux migrateurs transpyrénéens, Fasc. I. Rapport SRETIE/MERE/8815. Organbidexka Col Libre, Jasses. Available from http://www.migraction.net/index.php?m_id= 1522andfrmSite $=22$

Gatter W (1992) Zugzeiten und Zugmuster im Herbst: Einfluss des Treibhauseffektes auf den Vogelzug? J Ornithol 133:427-436

Gilyazov A, Sparks T (2002) Change in the timing of migration of common birds at the Lapland Nature Reserve (Kola Peninsula, Russia) during 1931-1999. Avian Ecol Behav 8:35-47

Birdlife International (2004) Birds in Europe: population estimates, trends and conservation status. Cambridge, UK

Jenni L, Kéry M (2003) Timing of autumn bird migration under climate change: advances in long-distance migrants, delays in short-distance migrants. Proc R Soc Lond B 270:1467-1471

Jonzén N, Linden A, Ergon T, Knudsen E, Vik JO, Rubolini D, Piacentini D, Brinch C, Spina F, Karlsson L, Stervander M, 
Andersson A, Waldenstrom J, Lehikoinen A, Edvardsen E, Solvang R, Stenseth NC (2006) Rapid advance of spring arrival dates in long-distance migratory birds. Science 312:1959-1961

Knudsen E, Linden A, Ergon T, Jonzen N, Vik JO, Knape J, Roer JE, Stenseth NC (2007) Characterizing bird migration phenology using data from standardized monitoring at bird observatories. Clim Res 35:59-77

Lehikoinen A (2009) Climate forcing on avian life history. Dissertation, University of Helsinki. Available from https://oa.doria.fi/ handle/10024/44864

Lehikoinen E, Sparks T, Zalakevicius M (2004) Arrival and departure dates. In: Møller AP, Fiedler W, Berthold P (eds) Birds and climate change. Advances in ecological research, vol 35. Academic, New York, pp 1-31

Lehikoinen A, Byholm P, Ranta E, Saurola P, Valkama J, Korpimäki E, Pietiäinen H, Henttonen H (2009) Reproduction of the common buzzard at its northern range margin under climatic change. Oikos 118:829-836

Miller-Rushing AJ, Lloyd-Evans TL, Primack RB, Satzinger P (2008) Bird migration times, climate change, and changing population sizes. Glob Chang Biol 14:1959-1972

Møller AP, Rubolini D, Lehikoinen E (2008) Populations of migratory bird species that did not show a phenological response to climate change are declining. Proc Natl Acad Sci USA 105:16195-16200

Moussus JP, Jiguet F, Clavel J, Julliard R (2009) A method to estimate phenological variation using data from large-scale abundance monitoring programmes. Bird Study 56:198-212

Newton I (2008) The migration ecology of birds. Academic, London

R Development Core Team (2006) R, A language and environment for statistical computing. R Foundation for statistical computing, Vienna. Available from http://www.Rproject.org. Accessed September 2006

Sokolov LV (2006) Effect of global warming on the timing of migration and breeding of passerine birds in the 20th century. Entomol Rev 86:59-81
Sokolov LV, Markovets MYu, Shapoval AP, Morozov YuG (1998) Long-term trends in the timing of spring migration of passerines on the Courish Spit of the Baltic Sea. Avian Ecol Behav 1:1-21

Sparks TH, Bairlein F, Bojarinova JG, Huppop O, Lehikoinen EA, Rainio K, Sokolov LV, Walker D (2005) Examining the total arrival distribution of migratory birds. Glob Chang Biol 11:22-30

Strandberg R, Klaassen RHG, Hake M, Olofsson P, Thorup K, Alerstam T (2008) Complex timing of Marsh Harrier Circus aeruginosus migration due to pre- and post-migratory movements. Ardea 96:159-172

Thorup K, Tøttrup AP, Rahbek C (2007) Patterns of phenological changes in migratory birds. Oecologia 151:697-703

Tøttrup AP, Thorup K, Rahbek C (2006) Changes in timing of autumn migration in North European songbird populations. Ardea 94:527-536

Tryjanowski P, Sparks TH (2001) Is the detection of the first arrival date of migrating birds influenced by population size? A case study of the red-backed shrike Lanius collurio. Int J Biometeorol 45:217-219

Vähätalo A, Rainio K, Lehikoinen A, Lehikoinen E (2004) Spring arrival of birds depends on North Atlantic oscillation. J Avian Biol 35:210-216

Visser M, Perdeck AC, Van Balen JH, Both C (2009) Climate change leads to decreasing bird migration distances. Glob Chang Biol 15:1859-1865

Walther GR, Post E, Convey P, Menzel A, Parmesan C, Beebee TJC, Fromentin J-M, Hoegh-Guldberg O, Bairlein F (2002) Ecological responses to recent climate change. Nature 416:389-395

Zalakevicius M, Bartkeviciene G, Raudonikis L, Janulaitis J (2006) Spring arrival response to climate change in birds: a case study from eastern Europe. J Ornithol 147:326-343 